\title{
Microvascular decompression of the trigeminal nerve: technical note
}

\author{
Ericson Sfreddo ${ }^{1}$
}

\begin{abstract}
The technique described by Jannetta uses Teflon "turfs" (polytetrafluoroethylene). With the technological advancement of materials it is increasingly harder to find Teflon in the market. The author describes a technique which uses a portion of a vascular prosthesis made of polyester (FlowNit Bioseal ${ }^{\circledR}$ ) manufactured by JOTEC ${ }^{\circledR}$ Gmbh reference 35B/1206. The use of this vascular prosthesis seems to be an effective alternative for intracranial neurovascular decompression. One of its advantages is having a circumferential format, which provides greater stability and safety to possible displacement.
\end{abstract}

\section{KEY-WORDS}

Trigeminal nerve, trigeminal neuralgia, decompression, surgical.

\section{RESUMO}

Descompressão microvascular do nervo trigêmeo: nota técnica

A técnica descrita por Jannetta utiliza "tufos" de Teflon (politetrafluoroetileno). Com o avanço tecnológico dos materiais, está cada vez mais difícil a aquisição de Teflon no mercado. $O$ autor descreve uma técnica utilizando uma porção de prótese vascular de poliéster (FlowNit Bioseal ${ }^{\circledR}$ ), fabricado por JOTEC ${ }^{\circledR}$ Gmbh referência 35B/1206. O uso da prótese vascular parece ser uma alternativa efetiva para descompressão neurovascular intracraniana. Possui a vantagem de apresentar o formato circunferencial, que permite maior estabilidade e segurança em possíveis deslocamentos.

\section{PALAVRAS-CHAVE}

Nervo trigêmeo, neuralgia do trigêmeo, descompressão cirúrgica.

\section{Introduction}

The classic approach for decompression surgeries of the trigeminal nerve uses portions of unthreaded Teflon as turfs that are interposed between the nerve and the vein or artery that compresses it. Given the difficulty to buy Teflon in the Brazilian market, the present paper describes a surgical technique using an alternative material.

\section{Surgical technique}

The patient is placed in decubitus dorsal with the shoulder on the side to be operated elevated. The patient's head is fixed with three pins and turned to the opposite side according to the technique described by Ojemann for approaches of tumors of the pontocerebellar angle. ${ }^{13}$ A suboccipital craniotomy of $3 \mathrm{~cm}$ of diameter with exposure of the crest of the transverse and sigmoid sinus is performed. The dura mater is opened, and the cerebellum is exposed. A gentle traction of the cerebellum is then performed so that the cisterna is opened and the cephalo-rachidian liquid is drained. Thus, a bigger space between the cerebellum and the posterior fossa bone is created, which allows little traction force in the spatula. The trigeminal nerve is identified, and the compression, be it arterial or venous, is undone. Then, a portion of vascular prosthesis made of polyester (FlowNit Bioseal ${ }^{\circ} 12 \times 6 \mathrm{~mm}$ ), manufactured by JOTEC ${ }^{\circledast}$ Gmbh (Germany) reference 35BI1206, is prepared (Figure 1). This portion of prosthesis is placed covering in a circumflex the trigeminal nerve, protecting it from the pulsatile action of the vessel (Figures 2 and 3 ). 


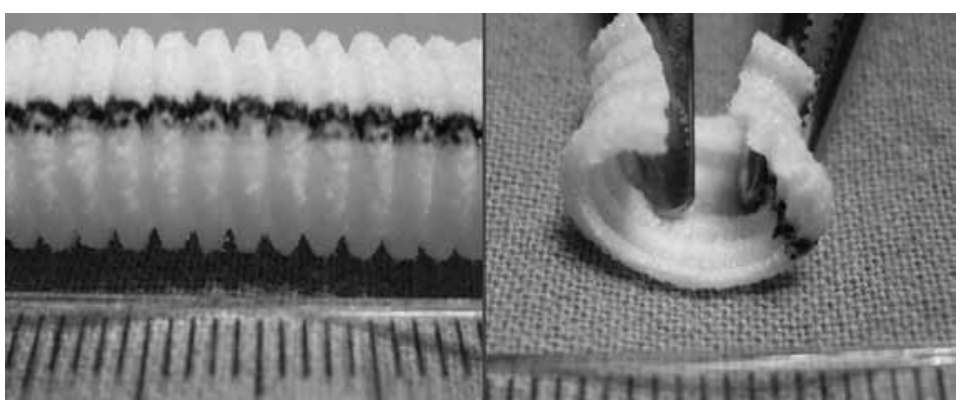

Figure 1. Preparation. (A) Vascular prosthesis made of polyester (FlowNit Bioseal ${ }^{\star}$ ) manufactured by JOTEC ${ }^{\oplus}$ Gmbh reference 35BI1206; (B) Portion of the prosthesis cut to allow circumflex fitting around the nerve.

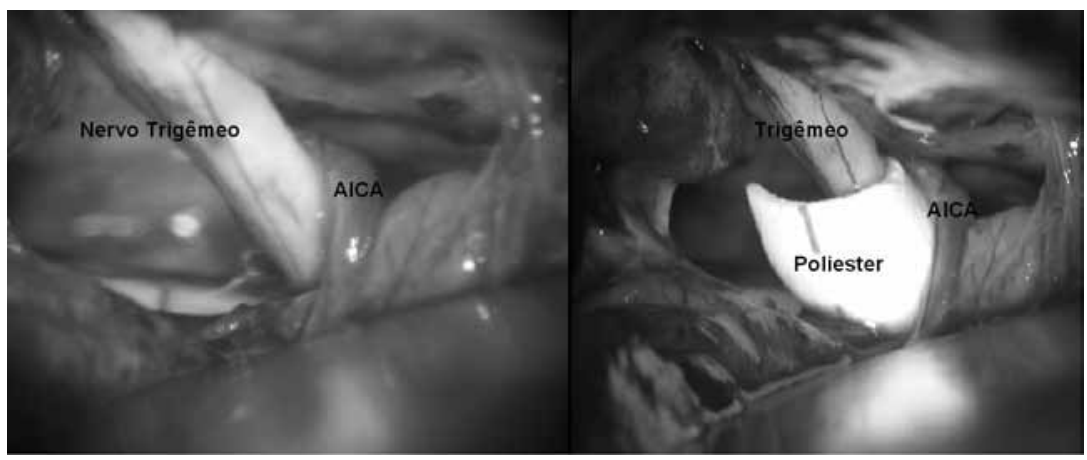

Figure 2. Example 1: polyester covering part of the trigeminal nerve where the neurovascular compression was.

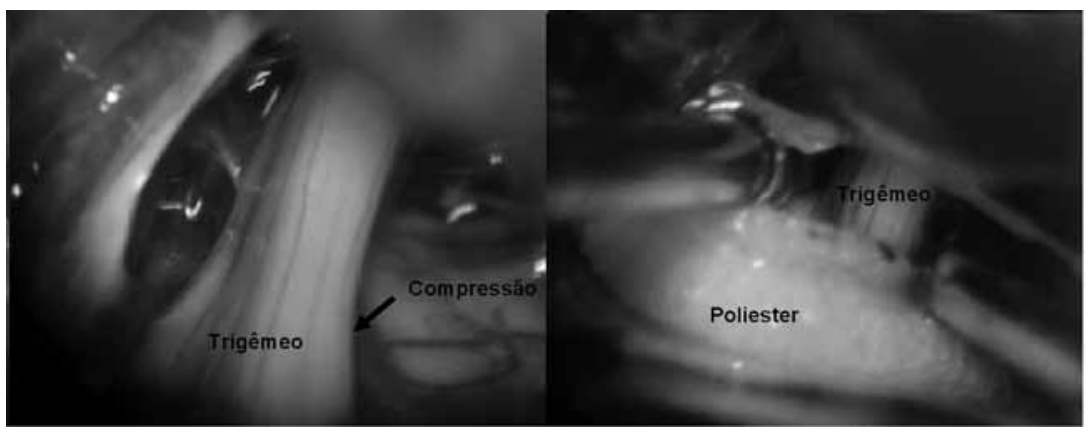

Figure 3. Example 2: polyester covering the trigeminal nerve completely, removing it from the arterial compression.

\section{Discussion}

Centuries ago painful facial syndromes were described by Avicenna (died in 1037 AD). In 1677, John Locke described a painful syndrome compatible with what is today called a trigeminal neuralgia. The term tic douloureux is likely to have been first used by Nicolas André in 1756 apud Brown et al. ${ }^{2}$

Without using a microscope, Dandy ${ }^{3,4}$ described for the first time the existence of a vascular compression of the trigeminal nerve in the posterior fossa in 66 of his 215 cases. Jannetta ${ }^{8}$, using a surgical microscope, demonstrated the existence of vascular compression in $90 \%$ of his patients operated for trigeminal neuralgia. Studies using an electronic microscope have demonstrated much demielinization in the nerve portion called Root Entry Zone in patients with trigeminal neuralgia when compared to the normal population. ${ }^{1,12}$

Current theory suggests that vessels of the posterior fossa, specially the superior cerebellar artery and the anterior and inferior cerebellar artery, become tortuous due to atherosclerosis and compress the trigeminal 
nerve in the Root Entry Zone. This zone is demielinized; consequently, there is a trans-axonal transmission between afferent and efferent fibers, and a "short-circuit" is formed with epileptiform activity in central connections of the trigeminal nerve. Hence, the phenomenon of paroxystic pain. ${ }^{6,711}$

The first neurovascular decompression was performed by Gardner and Miklos in the 1959's. ${ }^{5}$ In the following years, the technique was popularized by Jannetta and Rand. ${ }^{10}$ They introduced the use of the surgical microscope and supported that the neurovascular decompression of the trigeminal nerve was the standard technique for the treatment of trigeminal neuralgia. In 1976, Jannetta ${ }^{9}$ described a technique using portions of unthreaded Teflon to be interposed between the arterial or vein loop that compresses the trigeminal nerve. To date, the use of Teflon is the procedure of choice in the approach of neurovascular decompression, be it of the trigeminal nerve or not.

The technique described herein aims at broadening the therapeutic arsenal to the neurosurgeon that often faces the difficulty in finding Teflon available in the market or in its preparation since it requires time and knowledge of sterilization techniques.

\section{Conclusion}

The use of vascular prosthesis is an effective alternative to the use of Teflon in intracranial neurovascular decompression. Vascular prostheses are circumflex; this provides greater stability and safety in terms of displacement.

\section{References}

1. Beaver DL, Moses HL, Ganote CE. Electron microscopy of the trigeminal ganglion. 3. Trigeminal Neuralgia. Arch Pathol. 1965;79:571-82.

2. Brown JA, Coursaget C, Preul MC, Sangvai D. Mercury water and cauterizing stones: Nicolas André and tic douloureux. J Neurosurg. 1999;90(5):977-81.

3. Dandy WE. Sections of the sensory root of the trigeminal nerve at the pons. Bull John Hopkins Hosp. 1925;36:105-6.

4. Dandy WE. Surgery of the brain In: Lewin D. Lewis' practice of surgery. Hagerstown: WF Prior Co; 1945. p. 167-87.

5. Gardner WJ, Miklos MV. Response of trigeminal neuralgia to decompression of sensory root; discussion of cause of trigeminal neuralgia. J Am Med Assoc. 1959;170(15):1773-6.

6. Gardner WJ. Concerning the mechanism of trigeminal neuralgia and hemifacial spasm. J Neurosurg. 1962;19:947-58.

7. Gardner WJ. The mechanism of tic douloureux. Trans Am Neurol Assoc. 1953;3(78th Meeting):168-71.

8. Jannetta PJ. Arterial compression of the trigeminal nerve at the pons in patients with trigeminal neuralgia. J Neurosurg. 1967;26(1):Suppl:159-62.

9. Jannetta PJ. Microsurgical approach to the trigeminal nerve for tic douloureux. Progr Neurol Surg. 1976;7:180-200.

10. Jannetta PJ, Rand RW. Microentomy of the trigeminal nerve. Anat Rec. 1966;154:362.

11. King RB, Meagher JN. Studies of trigeminal nerve potentials. J Neurosurg. 1955;12(4):393-402.

12. Kurger L. Structural aspects of trigeminal neuralgia: a summary of current findings and concepts. J Neurosurg. 1967;26(Suppl 11):183.

13. Ojemann RG. Suboccipital approach to acoustic neuromas. In: Wilson CB, editor. Neurosurgical procedures: personal approaches to classic technics. Baltimore: Williams \& Wilkins; 1992. p. 78-87.

Correspondence address

Ericson Sfreddo

Rua Doutor Florêncio Ygartua, 270, cj. 1109, Moinhos de Vento

90430-010 - Porto Alegre, RS, Brazil

Telephone: (+ 55 51) 9316-0099

E-mail: ericson.neurosurgery@gmail.com 